\title{
FOR A PUBLIC SOCIOLOGY ON PARTICIPATORY DEMOCRACY Reflexive feedback on research conducted in an association
}

\author{
POR UNA SOCIOLOGÍA PÚBLICA SOBRE DEMOCRACIA PARTICIPATIVA \\ Reflexiones sobre una investigación realizada en una asociación
}

\author{
HÉLoïse NEz heloise.nez@univ-tours.fr \\ Université de Tours. France.
}

\begin{abstract}
This paper develops a reflexive approach on the relations between research and action in works on participatory democracy; a topic in which bridges are numerous between academic, political and activist fields. It aims at analyzing the impact of the close links between sociologists and actors on the methods and results of research and, reciprocally, the role of sociology in developing participatory practices. Relying on Michael Burawoy's reflection on "public sociology", our own research experience in an association, and other research studies conducted in Europe, we define five ways sociologists carry out research on participatory democracy in collaboration with the actors. Beyond a reflection on the social reception of our research, the challenge is to develop a critical and committed sociology on participatory democracy with a view to contributing to the political debate and public action from a critical viewpoint.
\end{abstract}

\section{KEYWORDS}

Critical sociology; Participatory democracy; Research-action; Social sciences epistemology.

\section{RESUMEN}

Este artículo desarrolla un enfoque reflexivo sobre las relaciones entre investigación y acción en los trabajos sobre democracia participativa, una temática en la que los vínculos entre los campos académicos, políticos y militantes son numerosos. El objetivo es analizar el impacto de las estrechas relaciones entre sociólogos y actores sociales en los métodos y resultados de la investigación y, al mismo tiempo, el papel de la sociología en el desarrollo de las prácticas participativas. Apoyándose en la reflexión de Michael Burawoy sobre la "sociología pública", en nuestra propia experiencia de investigación en una asociación y en otras investigaciones en Europa, se definen cinco posturas de sociólogos que trabajan en colaboración con los actores sociales sobre la democracia participativa. Más allá de una reflexión sobre la receptividad social de nuestras investigaciones, el desafío consiste en desarrollar una sociología a la vez crítica y comprometida sobre la democracia participativa, para contribuir al debate político y a la acción pública a partir de una capacidad de distancia crítica.

\section{Palabras clave}

Democracia participativa; Epistemología de las ciencias sociales; Investigación-acción; Sociología crítica. 


\section{INTRODUCTION*}

For a decade, research on participatory practices has proliferated as these processes aimed at engaging "ordinary" citizens (i.e. neither elected officials nor practitioners) in local public policymaking were spreading in Spain, Europe and on other continents (Font 2001; Santos 2002; Fung and Wright 2003; Avritzer and Navarro 2003; Bacqué, Rey and Sintomer 2005; Blondiaux 2008; Smith 2009; Bacqué et al. 2010). While there are many gateways between the academic, the political and the activist fields on participatory democracy, few works have developed a reflexive approach on the relationships between research and action. However, the research conducted in collaboration with local actors is quickly developing as attested to in France by the profusion of PhDs conducted in the context of an Industrial Training Convention for Research (French acronym CIFRE). The Cifre convention is a work contract subsidized by the National Association for Research and Technology (ANRT), which enables PhD candidates to pursue a thesis while being a wage earner in an association, a company or a public institution. While diversified financing schemes contribute to the development of research on participatory democracy and its dissemination in non-academic circles, this particular context of research production and its impact on results have yet to be analyzed. The aim of this article is to conduct an in-depth study of this methodological aspect by exploring the diverse positions of researchers interested in participatory democracy. The idea is to highlight the relationships between research, expertise and activism on participatory democracy by analyzing the impact of the close links between sociologists and field actors regarding research methods and results and, vice versa, the role of sociology ${ }^{1}$ in the development of participatory practices.

This epistemological and methodological analysis is in line with an article by Michael Burawoy entitled For public sociology (2005), which fuelled many debates across the Atlantic on the social role of sociology². Before him, Charles Wright Mills (1959) had already dedicated his essay on "sociological imagination" to the dissemination of knowledge to a non-university public. In this plea in favor of a sociology whose scope would go beyond academic circles, Burawoy invites sociologists to reach out to a public other than their peers and to commit themselves actively with their socializing groups. He develops a typology that distinguishes between four sociology subtypes: professional sociology, which produces knowledge for its peers so as to accumulate scores of knowledge; policy sociology, which is guided by a customer's demand; public sociology, which is intended for an extra-university public; and critical sociology, which is defined as the reflexive analysis of the tools and research programs of the discipline.

\footnotetext{
"Translated from the French by Patrice Cochet-Balmet.

${ }^{1}$ We use the term sociology in the broad sense, aware that other disciplines are also concerned with research on participatory democracy (political science, urban studies, history, etc.).

${ }^{2}$ See especially the collective book coordinated by Dan Clawson (2007).
} 
If the boundaries between these different types of sociology are porous, Burawoy defends a public sociology perspective to initiate and develop a dialogic relationship between the sociologist and the public, in which each comes forward with his or her goals and adjusts to the other. More than a simple incentive to reach out to new public, the American researcher chiefly invites sociologists to partake in the creation of public and to organize themselves into public. He thus encourages them to commit themselves with people and groups taking part in public life and engaged in political debates. As defined by John Dewey (1927), the word "public" here has a twofold meaning: as a space of discussion where different actors may meet and dialogue, and as a group of people seeking to influence politics. To a greater extent, Burawoy prompts researchers to ponder over the dissemination of the knowledge which they produce: "Knowledge for whom and knowledge for what?" (Burawoy 2005: 12). In doing so, he echoes questions raised by two of his predecessors in the presidency of the American Sociological Association (ASA): "sociology for whom?" (Lynd 1939), which is intended solely for an university public or other public; and "sociology for what?" (Lee 1976), which is centered on the objectives of society or also interested in the means necessary for their fulfillment.

Burawoy defines here the position and the interest of a public sociology in a general way in the sociological discipline, regardless of the objects of study. The objective of our paper is to develop this reflection on public sociology from a particular object of study, the processes of local participatory democracy. The literature on participatory democracy, participation and deliberation is plentiful and diverse. We focus here on the empirical research on participatory practices (participatory budgets, neighborhood councils, devices of participatory town planning, citizen juries, deliberative polling) on a local and regional scale. Our interest is in institutional forms of participation, even if associations and citizens can play a significant role in the emergence of these processes led by governments. The deliberative dimension of these devices can be important such as the case of citizen juries and deliberative polling, or less so as regards most of the other processes. Rather than approaching all the works on participation and deliberation, we chose to focus on this object of study because the researchers analyzing local participatory practices often maintain a more direct relationship with the action and pay particular attention to the impact of their studies on the transformation of participatory policies. As regards this aspect, research on participatory democracy bears a closer relationship to the militant fields (for example, research on an association or a social movement) insofar as they raise suspicions regarding the researcher's position at the same time in the academic sphere (which often accuses researchers of a lack of distance with their object of study) and with regard to those investigated (who can, on the contrary, blame researchers for a lack of commitment to action) (Broqua 2009). This question arises all the more when researchers share an affinity with the mobilizations or the participatory policies they observe. How can we reconcile this double role of researcher and activist, or at least of citizens committed or concerned by the participatory processes they observe? How can we answer the classic dilemma of any 
field work, that of the just measure between distance and commitment? And how can we reconcile rather than set apart these two positions in order to advance scientific research while contributing to the action on participatory democracy?

In an attempt to answer to these questions, our reflection is based upon a participant observation conducted from 2006 to 2009 as a part of the Institution-Citizen Partnership for Research and Innovation (French acronym PICRI) on local participatory practices in the region of Paris and in Europe. The specificity of these PICRI programs, which are sponsored by the Parisian region in the context of citizens' conception of science, derives from the collaboration of a team of researchers and field actors (in our case, an association) in the production of a research project and the dissemination of the research results. For three years, I have coordinated this research program as a research officer in the Association for Local and Social Democracy and Education (French acronym ADELS) within the framework of a CIFRE convention. ADELS brings together elected officials, practitioners from local government bodies and associations, researchers, activists and citizens who are committed at the local level with a view to exchanging and presenting proposals for the development of participatory democracy at the local scale. This historical actor in promoting the idea of decentralization and of local participation in France, which was created in 1959 within the popular education trend (Hatzfeld 2005, Roux 2011), now defends, some fifty years later, a conception of participatory democracy that provides a connection between the principles of political equality, social justice and self-organization (ADELS 2010). The activities of ADELS fall under several areas, from training sessions for local actors to studies of action through the organization of conferences (meetings on local democracy), as well as the publication of the monthly journal Territories and books on participation.

Building on this particular experiment, I shall first of all discuss how the research has been conducted in this associative context. What are the specificities of this sociological position and how does it differ from other ways of carrying out research? What are its contributions and limitations from the standpoint of research and of collaboration between actors and researchers? This personal experience may contribute to reflections on public sociology and participatory democracy because the objective of our program was specifically to undertake collaborative research between the university sphere and association actors on local participatory practices, and to reflect upon our approach. To analyze the diversity of views on public sociology and participatory democracy and to question the social role of such research more widely, this experiment will be cross-referenced with other ways to produce research in Europe through observations made of programs being conducted in four research centers of Spain, Italy, Portugal and Germany. By extrapolating our observations through the comparative method (Werner and Zimmermann 2004), I shall differentiate five typical positions held by sociologists on participatory democracy before drawing conclusions on the stakes involved in developing a sociology which is both committed and critical with a view to contributing to the action while maintaining the ability to react with critical distance. 


\section{RESEARCH CONDUCTED WITHIN AN ASSOCIATIVE FRAMEWORK}

Directly inspired by the University-Community Research Alliances (ARUC) in Quebec, the Institution-Citizen Partnerships for Research and Innovation (PICRI) are a financial tool set up in the region of Paris in 2006 to enable joint research between associations and public research organizations. The PICRI was promoted by the Citizen Science Foundation, an association created in France in 2002 with a view to democratizing science by engaging citizens in the production of scientific research. This conception of research is part of a more general trend which redefines the relationships between experts and laymen in scientific and technical issues. This movement, which has opened the door to a new way of doing research for the historical and sociological studies of the sciences (Collins and Evans 2002), was inspired in France by the publication in 2001 of the book by Michel Callon, Pierre Lascoumes and Yannick Barthe on technical democracy. By qualifying in these words the process to democratize the sciences and scientific techniques, the authors show that engaging citizens in political and technical decision making redefines the relationship between knowledge and power, and blurs the traditional borders between expert and "layman" knowledge. The idea was to consider the role of non-professionals in the production of scientific knowledge and to reallocate the "power to know" (Bonneuil and Gaudillière 2000) so that counter-powers may have independent means to acquire the available expertise.

The PICRI program in which I was involved from 2006 to 2009 was conducted in collaboration with ADELS and two research laboratories of the CNRS (National Center for Scientific Research of France) $)^{3}$. The research concerned local participatory democracy in the region of Paris and in Europe through a comparison of experiments conducted at different government scales in the region and of innovative experiments in other European contexts, primarily in Rome and Berlin. The purpose was to analyze the nature of the participatory practices, the dynamics created, and the achievements and limitations of such approaches. The research centered more specifically on the construction, the nature and the taking into account of citizens' knowledge in participatory processes by exploring the notion of citizen expertise, and on the genealogy of the practices by analyzing the transfer of knowledge and experiences from one site to the other. This experience seemed particularly interesting to us within the field of local democracy where bridges are already numerous between the university, associative and political spheres to generate joint knowledge between researchers and association officials. The aim of our program was thus to produce scientific knowledge on participatory democracy, and train local actors by integrating the findings of research

\footnotetext{
${ }^{3}$ The two research institutes were the Habitat Research Center $(\mathrm{CRH})$ and the Cultures and Urban Societies Laboratory (CSU). Marie-Hélène Bacqué and Yves Sintomer were the research coordinators. For more information about this research and training program, see the ADELS website, accessed on 24 October 2011: http://www.ADELS.org/formations_etudes/Picri.htm.
} 
and the dissemination of knowledge to encourage the actors to reflect upon their own practices.

The twenty researchers involved in the program were able to engage in exchanges with the participating practitioners in two distinct contexts. In the first instance, ADELS organized two training cycles in 2007 and 2008 on citizens' knowledge in participatory processes. These training sessions were targeted at local actors in the region of Paris. Fourteen people participated in the first cycle: two elected representatives, three territorial agents, three association professionals, four neighborhood councilors and two association activists from seven territories in the region (several districts of Paris, a suburb, a department, and an inter-municipal association). Twenty-three people participated in the second cycle, which centered on the issues of participatory town planning: two elected representatives, six territorial agents, two professionals, an association professional, three association activists, five neighborhood councilors and four academics from eight territories of the region. For the most part, these various actors had no links between them (aside from those from the same territory) as one of the goals of the training sessions was to create a network of actors interested in participatory democracy in the region. In conjunction with the training officer of the association, I organized four one-day sessions in Paris on the nature of citizen knowledge, the collection and exploitation of knowledge, knowledge exchange and the inclusion of citizens' knowledge in the public decisionmaking process. At the end of each cycle, we organized an academic stay in Rome followed by another in Berlin so as to widen the debates beyond the French context. Both the actors who had initiated innovative participatory practices and the researchers who analyze innovative processes intervened in these training sessions. We provided the participants with a series of questions and asked them to prepare their interventions with a view to responding to the participants' concerns, which were expressed at the beginning of each training cycle and set out in the objectives of each session. The researchers could thus present their work at different stages of the research process, from the first wording of assumptions up to the presentation of more advanced results. The stays, arranged in collaboration with La Sapienza University in Rome and the Centre Marc Bloch in Berlin, enabled the actors in the region to compare their own experiences to those of practitioners in other European contexts and to exchange ideas with the researchers analyzing these mechanisms.

In a second step, we organized a dialogue between the actors and researchers when the results of the PICRI program were presented at two international conferences held in Paris; the first on the genealogy of participatory democracy in 2008 and the second on citizen knowledge and urban issues in 2009 . Although the interventions were primarily undertaken by the researchers, half the participants were local actors (especially professionals of local government bodies and associations, but also some elected representatives and citizens involved in participatory processes in the region of Paris), who could thus gain knowledge of the results of our research and discuss them. A debate was also staged during the Local Democracy Meetings organized by ADELS in 2010, in which elected representatives, technicians, members of associations and neighborhood 
councils from different French cities participated. The aim was to present the first book of the PICRI program (Bacqué et al., 2010) and to take stock of this experiment between researchers and members of the association.

Contrary to the notion of the researcher in an ivory tower, this way of doing research is characterized by a permanent link with field actors when conducting research and by putting the results to public debate. I followed the same research approach for my PhD, prepared within the framework of the CIFRE convention at ADELS, which dealt with citizens' knowledge of town planning in Paris and Cordoba (Nez 2010). The purpose was to define the epistemological contribution of ordinary citizens to local public action and discuss elitist conceptions of democracy, according to which citizens are supposedly incompetent as soon as said conceptions extend beyond the sphere of their immediate interests. My method for analyzing participatory practices consisted in participant observation. The aim was an ethnographic-type investigation, characterized by a prolonged presence in the field and insertion in an interknowledge environment (Burawoy 1998; Beaud and Weber 2003; Cefaï 2003). In addition, I maintained a dialogue throughout the research manufacturing process with the wage earners and activists of ADELS. More formal debates on the results of my $\mathrm{PhD}$ were also held in collaboration with the practitioners and administrators of ADELS at several stages of the research. Upon completion of a three-year field study, I presented the first results of my PhD at the ADELS Summer University in 2009. The fact that these exchanges occurred before I started to write enabled me to incorporate the actors' remarks and questions upstream of the writing process. I also stepped into the debate at the Local Democracy Meetings organized by ADELS in 2010 in Grenoble, where I presented more advanced results of my research at a workshop.

\section{The contributions of a public sociology on participatory democracy}

This research conducted within an associative framework, in line with the "public sociology" position as defined by Burawoy, includes at least three types of contributions. Through regular exchanges with the field actors, I could first of all enrich the sociological analysis. Regarding the topic of citizen knowledge in participatory democracy, which was central to both the PICRI program and my PhD, the actors were prompted to reflect on their practices, which fed our sociological analyses. For example, when the typology of citizen knowledge in participatory democracy developed by Yves Sintomer (2008) -which distinguishes between ordinary reason, citizen expertise and political knowledge was put up for debate during a PICRI training session, the discussions with the field actors revealed new categories of analysis. An ADELS administrator, who was a former elected official in local democracy in a Paris district and is involved in numerous associations (especially Tam-Tam, an association specialized in town planning and party to a concerted plan of action for the "ZAC Paris Rive Gauche"4), insisted on the prominence

\footnotetext{
${ }^{4}$ For the "ZAC Paris Rive Gauche", one of the last major urban operations still in progress in Paris, a
} 
of the "network competence" of associations to form counter-assessments in view of the projects being undertaken by public authorities. Sharing the networks maintained by every member of an association in different spheres of local political life (town services, local elected officials, associations and participation authorities, press, universities, etc.) is indeed a skill in its own right which fuels the construction of associative expertise. The typology of citizen knowledge could hence be specified and developed in the field of participatory town planning through dialogue with field actors (Nez 2011).

These exchanges within the PICRI training sessions provided a unique field of observation for those paying attention to the relations between the positions and views of both the researchers and the actors on analysis categories which are also action principles (Boltanski and Thévenot 1991). The way actors understand the researchers' categories to feed and justify their discourse (by interrogating the impact of research on the action and hence its social effectiveness) can thus be analyzed, as well as how to merge the influence of the actors with the reflections of the researchers. For example, when I presented my typology of citizen knowledge of participatory town planning (which differentiates between local, professional and activist knowledge, as well as individual and collective knowledge) at the ADELS Summer University in 2009, a Tam-Tam activist showed his interest when describing how the action of his association had evolved: "The very existence of local knowledge, then of citizens' expertise, and finally political expertise follows the evolution I experienced during the different phases of the ZAC Paris Rive Gauche". Association officials have thus borrowed this typology to substantiate their discourses, enabling them to specify the contribution of ordinary citizens in participatory practices and legitimize their participation, even if certain categories (such as describing associative knowledge as "expertise", whereas the demands of associations, in the face of the expertise of town departments, is knowledge not to be partitioned) seem less useful than others to serve their purpose.

Finally, this position which could be depicted as "halfway" (since it involves both permanent links with the field actors and the researcher's autonomy when producing research) interestingly goes beyond an overhanging dimension of research typical of Pierre Bourdieu's epistemological position where the sociologist thinks he is imbued with a mission to unveil reality to the actors who are supposedly plunged in the world of illusion. It enables us to "take actors seriously" (Boltanski and Thévenot 1991) and to enrich the analysis of their reflections, while maintaining a kind of scientific distanciation. This method therefore interestingly combines taking observations into account from the individuals' viewpoint according to their judgment ability, and a critical approach that integrates factors which do not always appear to actors, such as social determinatives.

permanent committee was set up in 1997 to engage associations, neighborhood councils and institutional partners in discussions on the construction of the urban project. 


\section{Limitations as regards the relationship between actors and researchers}

There are, however, a number of limitations. The first one refers to a problem of scientific legitimacy, which I encountered repeatedly when conducting research in an associative framework. Although this research position in close connection with action often granted me privileged field access, with ADELS opening a number of doors through its networks, this was not always the case. ADELS is indeed identified as an activist, defending a certain conception of participatory democracy, which may prove problematic when meeting actors promoting another vision. Such was the case when I wanted to conduct an interview with the officials of the Campana Eleb consulting firm, whose participatory method is disparaged within the association (Nez and Talpin 2010). The activist position of ADELS may thus have made contacts more difficult, which prompted me to adjust my entrance according to my interlocutors (putting on my associative 'hat' or, more often, stressing my university background). In other cases, I was running the risk of being instrumentalized by the actors, for instance when, during a sociological interview, a cabinet member of the elected representative in charge of local democracy in Paris insisted that the association publish an interview by the elected official in its journal. The question that arises, as soon as field actors are 'input' into scientific production relates to researchers' autonomy. The ability to maintain a critical distance is an essential element to adopt a global approach to participatory practices, which incidentally was acknowledged by the majority of participants in the training sessions and the PICRI conferences, who enjoyed the opportunity given to them to take distance where they often feel as if they were "blindfolded". I came across this difficulty in particular in one of my fields, where the research report prepared in the PICRI context was censored by the elected official since he did not value the actions of his delegation enough. The aim of this intermediate report was to compare the participatory practices of several territorial government bodies headed by the Communist Party in the region of Paris. However, it was not in the interest of the local authority in question to emphasize the communist aspect of its management. Still, it was a local authority with which the ADELS had signed several contracts in the context of training sessions and of a conference which secured it a sizeable portion of its annual income ${ }^{5}$. This experience highlights the limitations to carrying out research in an associative context when there are conflicts of interest between the economic constraints of an association, which operates as an office for the development and design of certain activities, and the independence required of research activities.

In addition to these difficulties associated with the insertion of ADELS in the field of "participation practitioners" (Nonjon 2006), the main limitation of our investigation mechanism is the same one that researchers blame elected officials for implementing, participatory practices based upon "selective listening", that is to say, when such officials

\footnotetext{
${ }^{5}$ This question is all the more acute within the framework of ADELS, which after facing financial difficulties for several years, finally closed its doors in 2012.
} 
summarize the debates without giving decision power to the citizens. This conception of research is relatively conventional since final interpretation rests with the sociologist, even if fed considerably by discussions with the practitioners. In line with the reflections of STS (Science, Technology and Society) studies on the involvement of groups in decisions which concern them (Epstein 1995; Wynne 1996; Callon, Lascoumes and Barthe 2001; Barbot 2002; Collins and Evans 2002), it may be important to involve the actors much earlier in the research collective, and not only when returning the results. This was partially the case with ADELS when defining the research axes and when selecting the fields, but the discussions between actors and researchers have remained limited to that phase, without initiating a permanent dialogue throughout the research preparation process. Nevertheless, the employees and the activists of ADELS, far from being "laymen" on participatory democracy, may contribute to the research from their own expertise -in the same way as associations of AIDS activists, patients assert themselves as experts among the experts, by proposing new forms of experimental clinical treatments (Epstein 1995; Barbot 2002). Indeed, they are in possession of an "interactional expertise", which means "they have enough expertise to interact interestingly with participants and carry out a sociological analysis" (Collins and Evans 2002: 254). Starting from the technical democracy model, several ways to engage actors could thus be imagined in the research production process itself so that actors exert real influence on the elaboration of the problematic, the formulation of hypotheses or even the redirection of research under investigation.

Finally, while this double role of sociologist and activist enriches the analysis and motivates the carrying out of research, it is not free of tensions and contradictions. It is not only the classic question of the distance from our "pre-notions" or "values" - widely discussed in the literature since the works of Emile Durkheim and Max Weber- which arises, but more especially that of the conflicts between the values indispensable to any militant commitment and the process of research. As phrased perfectly by Bernard Lahire (2004: 60), "the action rationale requires unshakable faith, whereas the knowledge rationale may sometimes drive towards certain disenchantment of the world." I was faced with this challenge when writing my $\mathrm{PhD}$ thesis: activist commitment requires a strong conviction about an object which scientific research desecrates little by little. If my initial look at European experiments in participatory democracy was not naive, it still remained enthusiastic. However, as the field survey unfurled, a growing doubt crept in on the scope of the participatory processes as well as on the researcher's role in the development of these experiments, which is partially linked to my study cases. In Cordoba, the municipal team abandoned the participatory budget eight years after it was launched following an eventful history which led them to revise the objectives of political equality and of social justice. In Paris, where participatory democracy was at the heart of Bertrand Delanoë's program in 2001, its prominence was only marginal during the 2008 elections. The sociological analysis thus reveals the degree of discrepancy between the participatory ideal advocated by ADELS in its manifesto (ADELS 2010) and the practices effectively implemented in the European context. 


\section{A TYPOLOGY OF PUBLIC SOCIOLOGY POSITIONS ON PARTICIPATORY DEMOCRACY}

During my research on participatory democracy in an associative context, I maintained various relationships with the action. I mainly tried to conduct the research in permanent interaction with the actors and to put the results of my research to debate with those investigated following a "public sociology" perspective as defined by Burawoy and as I described previously. But I also took part in public or internal debates organized by public institutions, political parties or associations as an academic expert (which is sometimes more akin to the "policy sociology" position in Burawoy's typology), contributed to the training sessions of local elected representatives, or helped inhabitants to build an argument to assert their point of view in front of public authorities. To question the researchers' social role and their impact in the development of participatory practices, it is important to distinguish these various activities which bring together several positions of public sociology. The elaboration of a typology allows us to go beyond the general definition proposed by Burawoy and to approach the multiplicity of positions which the researchers working on participatory democracy maintain with the action. The objective is to clarify what we understand by "public sociology" with regard to this particular object and to estimate its impact both on the research and on the development of participatory practices according to the degree of commitment of the researchers in the action.

To elaborate this typology, I shall rely not only on my own personal experience within the PICRI program, but also on other research programs in Europe. It is a question of giving a more general reach to my typology, by analyzing the research conducted by centers that are particularly active in the participatory democracy field. This selection is not exhaustive, but it allows obtaining a relatively wide panel of European research on this topic. To choose these study cases, I followed several criteria: sociological research conducted on local participatory practices, the diversity of institutional and scientific contexts in Europe, the involvement of researchers in the action and/or in reflexivity towards the action, as well as a context of collaboration with public institutions, associations or other citizens' groups. The objective was to extrapolate my own observations made within the framework of ADELS and the two centers of the CNRS by diversifying scientific traditions and institutional contexts. I observed the methods used by the researchers working on participatory democracy in four European research centers: the Institute for Advanced Social Studies (IESA) in Cordoba, the Centre for Social Studies (CES) in Coimbra, the Centre Marc Bloch in Berlin and La Sapienza University in Rome. The observation was facilitated by the fact that the majority of these researchers were involved in the PICRI program, which allowed me to exchange my views with them during numerous scientific meetings (both conferences organized by the PICRI in 2008 and 2009, but also five international conferences held from 2008 to 2011) and numerous academic stays (two short-term stays in Rome and in Berlin, and five four-month stays in Cordoba from 2006 to 2010). We exchanged information about our research practices during scientific discussions intended to develop reflexivity on the relations between research and action, and in more informal discussions. 
From a Weberian perspective, the goal of the typology is to establish semi-abstract ideals, knowing that these unreal constructions do not exist as such in reality and that combinations between the various types are possible (Weber, 1947). If the various positions held by sociologists on participatory democracy aims at clarifying the analysis by simplifying reality, my stand within the PICRI program and my PhD show that a researcher can move between these various roles according to the expected results from the point of view of the research and the action. I suggest distinguishing five typical ideals of distinct ways to do research in collaboration with the actors on participatory democracy, knowing that the researchers often combine several positions: the "dialogist sociologist", the "organizer sociologist", the "practitioner sociologist", the "expert sociologist", and the "compagnon de route sociologist". While the "dialogist sociologist" attempts to establish a dialogue and a process of mutual education with his or her audience, the "organizer sociologist" does not only put the results of research to debate, but integrates the actors into the research collective. The "practitioner sociologist", on the other hand, takes part directly in the action as an internal or external consultant by using methods originating from the social sciences. The last two positions, those of the "expert sociologist" and the "compagnon de route sociologist", play the role of advisor to the actors in a contractual or militant relationship. These various positions distinguish themselves according to the degree of the researchers' commitment to the action (from a position of dialogue to the direct involvement in activities through organization and advice), the type of commitment (academic, professional, activist), the nature of their relationships with the practitioners (formal or not, contractual, friendly, etc.), the place research occupies in their approach (as the main objective or as a tool for the action), and their impact on the action (more or less strong and direct).

The distinction between these various positions aims at developing the typology of Burawoy from the specificities of research on participatory democracy by being interested in the forms characterizing both "public sociology" and "policy sociology" in this object of study. I shall not develop here the position of the "pure scientist" (which corresponds to the positions of "professional sociology" and "critical sociology" in Burawoy's typology), who seeks the recognition of peers rather than to exert some influence on the reality he or she studies, since sociologists working on participatory democracy are often involved in their object and/or their research fields 6 . This specificity of the thematic of participatory democracy can be understood not only in terms of the profile and the trajectory of the researchers who choose to work on this question by combining a scientific approach with a political reflection and even an activist commitment, but in terms of the interest which the actors show towards the research conducted on this theme by reading the work of the researchers and seeking expertise within the framework of their activities. Thus, here as

\footnotetext{
${ }^{6}$ Research can certainly be undertaken in this perspective on local participatory processes, but given the angle of my paper, I focus here on sociologists' positions to deliberately seek a link with the local actors and an impact on the action.
} 
in militant fields, the distance to the object and the place the researcher occupies within the environment studied are chosen not only by the researcher, but also co-built by the group (Broqua 2009).

\section{The dialogist sociologist}

The "dialogist sociologist" corresponds to Burawoy's definition of "public sociologist" in its "organic" version. These sociologists initiate a mutual dialogue and learning process with their public: "In the same genre of what I call traditional public sociology we can locate sociologists who write in the opinion pages of our national newspapers where they comment on matters of public importance. [...] There is, however, another type of public sociology -organic public sociology in which the sociologist works in close connection with a visible, thick, active, local and often counter-public. [...] Between the organic public sociologist and a public is a dialogue, a process of mutual education" (Burawoy 2005: 7-8). The main activity of this kind of public sociology hence consists in initiating a dialogue between sociologists and their public, which implies an epistemological split and especially allows returning scientific research results: "We have spent a century building professional knowledge, translating common sense into science, so that now, we are more than ready to embark on a systematic back-translation, taking knowledge back to those from whom it came, making public issues out of private, and thus regenerating sociology's moral fiber" (Burawoy 2005: 5).

This is the main stance we adopted in the context of the PICRI program and which I followed when writing my $\mathrm{PhD}$, whereas these approaches are characterized by two features, as we could see: sociologists carry out research in close connection with field actors and organize public debates about their results. As I described in the first part of this paper, a dialogue between actors and researchers was organized at several stages of the research manufacturing process. It is also this position of research that prevails among the researchers working on participatory democracy at the Centre Marc Bloch in Berlin and at La Sapienza University in Rome. When they observe experiments of participatory budgets in the Berlin region, processes of participatory town planning in a district of Berlin or a participatory budget in a district of Rome, these researchers conduct their work by immersing themselves in the field (often developing long-term ethnographical inquiries, which sometimes brings them to live on their research field) to maintain close relations with the institutional and social actors. They then put to debate the results of their research to return their work to those investigated and to begin a discussion with the members of institutions, foundations, associations and/or citizens' groups. This was, for example, the approach followed by Carsten Herzberg and Cécile Cuny when they conducted research on participatory budgets in Lichtenberg and in Potsdam on the one hand, and on participatory practices in the district of Marzahn Nord on the other (Cuny and Herzberg 2008, Cuny 2009).

This practice of public sociology is founded on alternating moments when researchers discuss among themselves in a "confined" conception of research in laboratories, 
and others when sociological knowledge is discussed "outdoors" (Callon, Lascoumes and Barthe 2001). It is thus not a question of eliminating the experts, but of organizing cooperative research between specialists and "laymen" by establishing spaces of dialogue between "those whose job is to produce knowledge and those who are the immediate or unknown public" (Callon, Lascoumes and Barthe 2001: 67). As the theoreticians of technical democracy define it: "To speak about outdoor research is to underline a form of commitment in which the formulation of problems, the modalities of application of knowledge and the know-how produced, as well as the necessary opening of the research collective prevail" (Callon, Lascoumes and Barthe 2001: 149). This new form of organization and integration of research in society allows investigating new ways of doing research, which may integrate demands which the researchers would not have thought about before. This alternation between laboratory research and outdoor research enables us to combine activist commitment and scientific distanciation at the same time, that is to say, to take the actor' discourses seriously (Boltanski and Thévenot 1991) and to maintain the autonomous production of research.

\section{The organizer sociologist}

The "organizer sociologist" offers another way of doing research wherein actors join the research collective. In this case, it is not the researcher who observes and interprets reality, but the sociologist who creates a process for the actors themselves to be able to observe and interpret their reality. This "research-action" design was developed in France in the late 1970s around the concept of "sociological intervention" and promoted by the team of Alain Touraine at the Center for Sociological Analysis and Intervention (French acronym CADIS). Its aim is not only to produce a sociological analysis, but also to promote reflexivity among the actors and to help them get organized: "To talk about intervention instead of experimentation is to pursue an action at the same time as a knowledge goal" (Touraine 1978: 188). This sociological intervention approach has, however, various limitations in the French context from the viewpoint of cooperation between actors and researchers (in the end it is the sociologists who writes and not the actors) that results in action, which is reduced in the majority of cases.

The situation is different in Latin America and in Spain, where the research-action method has had a notable influence on the training of participatory democracy practitioners. In 1996, the sociologist Tomas R. Villasante, who has written several books on participatory democracy and social transformation (Villasante 1995; 2006), created a master's course in research and participatory action at the Complutense University of Madrid intended for students and local government practitioners. His objective was to teach new methodologies to work on participation based upon Paulo Freire's pedagogy (1974) and the participatory research-action developed in the 1970s and 1980s in Latin America according to which citizens themselves decide on the possible alternatives to the problems they share. In this respect, this research position is closer to Gramsci's notion of "organic intellectual", as far as "the [organic] intellectual 
has to be thought-provoking, for the members of the class with which he is organically bound, raising their awareness of their community of interests and creating within this class a conception of the homogeneous and autonomous world" (Piotte, 1970: 19). The master's courses held in Madrid, but also in Barcelona, Seville and Bilbao, have had a considerable impact on participatory practices in Spain: more than half the experiments in participatory budgets, for example, initially hired people who had been trained there (Ganuza 2010: 34) I studied organized training sessions in participatory budgets based on this researchaction approach. In Cordoba, Ernesto Ganuza (a former student of Villasante) developed participatory methodologies to train the agents and representatives of the first participatory budget model (from 2001 to 2003). At the Centre for Social Studies in Coimbra, Giovanni Allegretti organized training sessions for municipalities wishing to create a participatory budget on the basis of Paulo Freire's pedagogy. By encouraging cities to set up such processes, these training sessions contributed to promoting these mechanisms in Portugal, which grew from about ten in 2009 to thirty-four in June 2011 (Allegretti 2011).

We have not adopted this research-action position in the context of our PICRI program since there is a risk of creating confusion between the role of the actors and that of the researchers. While it underlines the advantage of going further in associating actors to the production of research, this impact on action is sometimes detrimental to the quality of research. While the master's course in Spain has had an undeniable impact on the quality of methodologies used in participatory processes, the results in terms of scientific research are not as convincing, which, on the other hand, was not Villasante's main objective. In France, this method was used as a part of another PICRI program entitled "Renewing the practices of urban project conception: for a closer monitoring and a stronger cooperation between town practitioners, associations and citizens in the region of Paris", with whom we organized the conference on citizen knowledge as part of the urban issue in 2009. Under the leadership of Agnès Deboulet, this program was conducted in collaboration with CNRS laboratories specialized in urban studies, the International Association of Technicians, Experts and Researchers (AITEC) and tenants committees. The research-action approach has enabled consolidating groups of inhabitants and prompted researchers to join their struggle, especially with regard to coordinating actions against the demolition of working class areas. Nevertheless, the shortcoming was to make it more difficult, if not impossible, to access certain pieces of information held by institutional actors, whereas researchers were seen as being on the inhabitants' side.

${ }^{7}$ Former students of Tomas R. Villasante have recently published a methodological guide on this research-action method applied to participatory practices (Ganuza et al., 2011). 


\section{The practitioner sociologist}

In connection with the occupational training sessions we have described above, researchers may at times become directly involved in the setting up of participatory processes through the use of methods originating from the social sciences. This type of researcher is then a "practitioner sociologist" who plays a direct role in the action by taking on, for example, responsibilities inside a local administration or by intervening as an external consultant. If the involvement by such sociologists enables setting up innovative participatory practices, they are often challenged when developing a critical approach to a process which they contribute to implementing. This is, for example, the stance adopted by Ernesto Ganuza, who played a consultant role with the municipality of Cordoba in setting up a participatory budget on the basis of participatory methodologies. Employed by the municipality, he has played a decisive role in setting up and defining the methodology of the first participatory budget model in Cordoba. As a researcher at the Institute for Advanced Social Studies (IESA), he organized deliberative polling on the practice of the botellón, or outdoor binge drinking gatherings, in Cordoba (Cuesta et al. 2008) and on water management in the region of Andalusia (Ganuza, Garrido, Lafuente 2009; Jorba 2009). Within the framework of another form of participatory mechanism, in 2006 the Italian researchers involved in the PICRI began work to create a "Citizen Town Hall" in the first district of Rome (the historical quarter). The Citizen Town Hall is a public space for informing, debating and presenting proposals on the development of the local town planning scheme of this capital city (Cellamare 2006). The researchers played a full role in implementing this Citizen Town Hall by lending it scientific credibility and by offering local associations and the district administration cultural, technical and organizational support. In these cases, the sociologist takes part in the action as a practitioner involved with the public authorities, more than as an expert sociologist from an external position.

This practitioner sociologist position is shared by the researchers who experiment with innovative methods as part of randomly selected participatory processes, such as citizens' juries and deliberative polling. The Planungszellen (planning units) and citizens' juries were invented in the early 1970 s by two fully-fledged sociologists, with a few months interval in Germany and in the United States. In the same quest for new democratic forms of town planning, Peter Dienel (1978) and Ned Crosby (2003) created a process for a small group of randomly selected citizens to deliberate on a public policy issue and to formulate a series of recommendations after receiving information from specialists. Once this university experiment moved into the field of local participatory democratic practices, the researchers have continued to play an essential role in organizing the procedure, guaranteeing the pluralism of information and the smooth proceeding of the debates. Their role is similar in the context of deliberative polling; a procedure engineered by the American political scientist James Fishkin (1995) in the early 1990s consisting in using the opinion poll method (i.e. the selection of a representative sample of the population) and in organizing a debate between the people selected over several days on the basis of pluralistic information so as to enable each participant to voice an 
informed opinion on a given topic. These positions are at the origin of a particular commitment by sociologists, which privileges the effects of their methodologies and focuses on the importance of the action to the quality of scientific research.

\section{The expert sociologist}

Less involved in the action, the "expert sociologist" advises the actors through a conception of sociological expertise guided by the client's demand. The involvement by these sociologists in the action is less extensive than in the case of the practitioner sociologist. Indeed, it is often about occasional interventions with a public institution to give advice about their participatory policies or to propose an evaluation of them. While this conception of the expert sociologist often corresponds to a will to disseminate the research experience on participatory democracy to institutional actors, it is closer to Burawoy's conception of policy sociology: "Policy sociology is sociology in the service of a goal defined by a client. Policy sociology's raison d'être is to provide solutions to problems that are presented to us, or to legitimate solutions that have already been reached" (Burawoy 2005: 9). Sociologists are often invited by local communities to intervene in participatory democracy as "university experts", that is, to present their work, to summarize debates during actors' meetings or to take part in the assessment by authorities of the processes. We prefer to use here the term "expert sociology" rather than "policy sociology" to emphasize this dimension of expertise typical of sociological research. This position secures privileged field access and better knowledge of the actors' opinions by multiplying "offthe-record" discussions outside official interviewing situations, but there is a risk of instrumentalization by some actors (especially institutional ones) and of losing credibility with others (the association actors and citizens involved in participatory processes).

This position has, at times, been adopted by the majority of the researchers on the sites I analyzed, in particular by Giovanni Allegretti who has requested in every corner of the world to communicate his expertise on participatory budgets (with local authorities, international institutions, associations and citizens' groups, etc.). I have also adopted this position repeatedly within the framework of my research. As I had been conducting my research in the 20th borough of Paris for a year and a half, I was invited by the new municipal team to partake in a restricted think tank on the evolution of local democracy as a university expert. The aim of the work group composed of local elected members, neighborhood councilors and of two experts (Julien Talpin and myself) was to write out a new neighborhood council charter. The group met some ten times from May to July 2008, where we gathered the opinions of key participation actors in several Parisian boroughs and other cities, and debated internally. The integration of this restricted group has proven quite interesting for my research since it has secured me behind-the-scenes access to municipal power holders (especially the discussions inside the mayor's cabinet), where I could observe lively debates which were not expressed publicly. However, the elected official in charge of participatory democracy borrowed our scientific justification of random selection as a means to attract new public and diversify the participants' 
sociology in order to push through a reform to increase the prominence of randomly selected members in the neighborhood councils of the 20th borough ${ }^{8}$. Still, he was not too keen on broadening participation to other social categories as his main concern was to differentiate from the participatory practices of the previous mayor, and especially to reduce the role of counter-power acquired by certain neighborhood councils. Under his mandate, the impact of our sociological expertise on action diminished in a possibly harmful manner, and the neighbourhood councils declined sharply in the $20^{\text {th }}$ borough. Moreover, our intervention was also rather badly perceived by some neighborhood councilors and association actors, which may then thwart field access.

\section{The "compagnon de route" sociologist}

Finally, researchers' involvement with local actors, institutions or citizens' groups is sometimes more akin to an activist than a contractual position. In this sense we are talking of a "compagnon de route sociologist", which refers to the position of the intellectuals who accompanied the Communist parties in Europe by sharing a number of ideas, but without taking out a membership card. This affinity was present in the two Western countries which had a powerful Communist party after the Second World War, namely France and Italy. This committed position with participatory democracy practitioners facilitates field access and boosts contribution to action at the risk, however, of losing face before other actors (for example the institutional actors when getting involved with an association or a social movement). This perspective whereby sociologists provide friendly support to ideologically akin actors is frequently adopted by the researchers who work on participatory democracy in the research centers I selected in Europe. In particular, it is the approach Carsten Herzberg took when analyzing the participatory budgets in the region of Berlin while contributing to defining the outlines of an academic expert and a political militant invested locally, or of numerous French and foreign researchers who followed the experience of the participatory budget of institutions of higher education in the region of Poitou-Charentes (Sintomer, Talpin 2011).

It is also with this perspective in mind that I have become involved in the local group of the Greens in the 20th borough or in a citizens' collective in Belleville. In Belleville, the members of the collective for revaluation of the neighborhood, whose meetings and activities I attended for more than a year, have gradually prompted me to become more than a simple observer by challenging me on issues of methodology (to design, for example, a questionnaire to collect the opinions of passers-by on the condition of the Belleville boulevard). I accompanied the group in some of its activities, while lending a sociological eye, as I continued to observe it in the context of my research. On the other hand, the

\footnotetext{
${ }^{8}$ Since their creation in 1995 in the $20^{\text {th }}$ borough, the neighborhood councils had been composed of one third political activists, one third association officials and one third citizens who were randomly selected from electoral rolls. In 2008 , the proportion of randomly selected neighborhood councilors increased to $51 \%$.
} 
Green activists invited me to present my research at several stages of its progress at their weekly debates. I thus presented the first findings derived from a one-year field investigation on the Parisian neighborhood councils in 2007, which enabled me to engage in an enriching dialogue with certain participants. For instance, a neighborhood councilor, who incidentally is also a Green activist, drew my attention to the unequal social distribution of occupational knowledge within such a local participation process. In 2011, I spoke again as a part of a "citizen training" cycle on participatory democracy, which enabled me to return the results of my PhD to a number of actors I met on the field. Generally speaking, I often reply positively to the requests from actors involved in participatory democracy, especially in the context of training sessions for elected members (above all the Communist Party in France) as the objective is to develop the social usefulness of my research by attempting to influence their practices.

\section{A difficult just term between commitment and distance}

By varying the degrees and modes of researchers' commitment to action, these five positions produce different results as regards research as well as practices. They reveal the challenges sociologists face to maintain a critical distance with respect to their object of study from the moment the research work goes hand in hand with a commitment to practitioners. Indeed, the researcher runs the risk of becoming an auxiliary to a movement or a policy and the actual effects on discourses and participatory practices do not always turn out as expected. However, while there is a risk in serving as scientific support for elected officials to legitimize their practices, which are sometimes quite far from the objectives, these positions typical of a sociologist committed to action also show that research may be effective from a social standpoint.

From my viewpoint, what is at stake is the development of a sociology on participatory democracy which is both critical and committed so as to contribute to the political debate and public action through the ability to maintain a critical distance. I agree with Philippe Corcuff (2004: 176) when he suggests outlining "a direction where commitment rests on the achievements of now autonomous social sciences". In the face of Weber's opposing relationship between politics and science as a vocation, which distinguishes two kinds of completely heterogeneous problems (Weber 1919), the idea is to "consider both tensions and bridges between the scientist's ethics and the activist's ethics, by giving up on dreams of purification" (Corcuff 2004: 181). As stated in turn by Lahire $(2004: 59,65)$ from another epistemological position which defends the specificity of scientific skills", "It

\footnotetext{
${ }^{9}$ Far from the clear separation between "social sociology" and "experimental sociology" presented by Lahire, Corcuff suggests, as I have tried to do in my research, to "think at the same time resemblances and differences, continuities and discontinuities between professional sociology and actors' sociology, but also interrelations (thus in both directions: the formalization of concepts from common cognitive-discursive plans and the usage by the actors of notions coming from the social sciences)" (Corcuff 2004: 188-189).
} 
only remains to consider the concrete routes through which the sociologists may, without killing or weakening the scientist inside them, usefully contribute to reflection and public action". The idea is then to combine a public and a critical sociology approach, which according to Burawoy (2005: 10), are the "conscience" of policy sociology and of professional sociology, to continue to develop reflexive knowledge on participatory democracy. Contribution to the political debate and to public action is thus based on a position which is committed but autonomous with respect to the political and social field.

\section{ConcLusion}

With regard to my research experience in an associative context and to the various positions sociologists develop on participatory democracy, I would like to underline the interest, from a scientific point of view, of making a strong commitment to the participatory practices we observe. In a first instance, a public sociology position provides us access to the field and, more particularly, behind the public scenes to which we have access only when we are involved in the action. Often, the most interesting observations take place in these exchanges behind the public scenes, which also permit us to gain an understanding of what happens in the public arena. Collaboration with actors also allows us to enrich our works with the reflexivity they develop with regard to their practices, and thus develop new categories of analysis. The question that arises, however, is the autonomy of researchers and their capacity to maintain a critical distance. We can observe effects of censorship by our institutional interlocutors, but also of self-censorship when we do not want to hurt actors who are close to us or disparage a heart-felt initiative. The challenge is to not minimize the critical dimension of our works, knowing that they are going to be read by others, both by those we observe and whose cause we support and by those who are opposed to the participatory practices we study and could use these works to criticize them. The double role of researcher and activist can also make both positions more difficult to hold, as conducting research can lead to a certain disenchantement of the world. In spite of these limitations, it seems to me that the game is worth the candle from the point of view of scientific research.

But what is the impact on political action? A public sociology approach mainly allows proposing a critical analysis of a participatory initiative to help the actors to stand back and reflect on their own practices. Critical analysis is certainly not reserved for researchers as some practitioners deeply reflect on their action, but researchers can facilitate this taking of critical distance. Another contribution to the action can be seen in terms of the dissemination of methods and experiences: research provides methodological equipment and permits capitalizing on the experiences. The training sessions organized by ADELS within the PICRI program played this role with actors invested in participatory democracy in the region of Paris. In the same way in Spain, the researchers played an important role in the adoption of participatory practices by the local authorities but also by some social movements by spreading methods originating from the social sciences. From 
its emergence in mid-May 2011, some students in master's degree programs on participatory methodologies participated in the Indignados movement by moderating large assemblies, and influenced their functioning through the dissemination of methodological guides which circulated in militant circles (Lorenzana, Basagoiti, Bru 2001; Lorenzo, Martínez 2001). The effects of public research on participatory democracy can thus go beyond the institutional sphere and come to strengthen social movements.

However, some conditions must be in place so that the research can have an impact on the action. The first one is the existence of spaces of dialogue between actors and researchers at the various moments of the research, not only at the time of returning the results to those investigated, but also during the formulation of problems and the development of the initial hypotheses. Beyond the sphere of ethnographical research, it is necessary to establish specific spaces to create this dialogue through financing aimed at developing partnerships between research laboratories and associations as occurs in the PICRI programs. "Confined" research does not transform itself into "outdoor" research just like that. In the context of the increasing precariousness of associations in a number of European countries, it requires financial means to create spaces to establish a dialogue between interlocutors who are not still used to working together. The second condition is that, in their activities and objectives, researchers must disseminate their research beyond academic circles. To develop in the scientific field, public sociology requires a transformation of academic rules, which often privilege the dissemination of works in reviews only read by peers or in conferences closed to the general public ${ }^{10}$, to ensure that other ways of conducting and spreading research are also valued in academic careers.

\section{REFERENCES}

ADELS, 2010. "Egalité politique, justice sociale et auto-organisation: manifeste pour réinventer la démocratie." Territoires 508:19-20.

Allegretti G. 2011. "Europe du Sud : des hauts et des bas." Territoires 519:30-31.

Avritzer, L. and Z. Navarro. eds. 2003. A inovação democrática no Brasil: o orçamento participativo. São Paulo: Cortez.

Bacqué, M.-H., Rey, H. and Y. Sintomer, eds. 2005. Gestion de proximité et démocratie participative: une perspective comparative. Paris: La Découverte.

Bacqué, M. H. et al. eds. 2010. La démocratie participative inachevée: genèse, adaptations et diffusions. Paris: ADELS/Yves Michel.

Barbot, J. 2002. Les malades en mouvements: la médecine et la science à l'épreuve du sida. Paris: Balland.

\footnotetext{
${ }^{10}$ On the difficulties reconciling intellectual work and anti-establishment action in the academic sphere, see the stimulating article of Pierre Rimbert (2011).
} 
Beaud, S. and F. Weber. 2003. Guide de l'enquête de terrain: produire et analyser des données ethnographiques. Paris: La Découverte.

Blondiaux, L. 2008. Le nouvel esprit de la démocratie: actualités de la démocratie participative. Paris: Seuil.

Boltanski, L. and L.Thévenot. 1991. De la justification: les économies de la grandeur. Paris: Gallimard.

Bonneuil, C. and J. P. Gaudillière, eds. 2000. "Savoir c'est pouvoir: expertise et politique." Mouvements 7:4-76.

Broqua, C. 2009. "L'ethnographie comme engagement: enquêter en terrain militant." Genèses 75:109124.

Burawoy, M. 1998. "The Extended Case Method." Sociological theory 16/1:4-33.

Burawoy, M. 2005. "For Public Sociology." American Sociological Review 70/1:4-28.

Callon, M., Lascoumes, P. and Y. Barthe. 2001. Agir dans un monde incertain: essai sur la démocratie technique. Paris: Seuil.

Céfaï, D. 2003. "L'enquête de terrain en sciences sociales". Pp 465-615 in L'enquête de terrain, edited by D. Cefaï. Paris: La Découverte.

Cellamare C. 2006. Roma-Centro. Dal laboratorio alla 'Casa della Città'. Roma: Palombi Editori.

Clawson D. eds. 2007. Public Sociology: Fifteen Eminent Sociologists Debate Politics and The Profession in the Twenty-First Century. Berkeley: University of California Press.

Collins, H. and Evans, R. 2002. "The Third Wave of Science Studies: Studies of Expertise and Experience." Social Studies of Science 2: 235-296.

Corcuff, P. 2004. "Sociologie et engagement: nouvelles pistes épistémologiques dans l'après-1995." Pp. 175-194 in A quoi sert la sociologie? edited by B. Lahire. Paris: La Découverte.

Crosby N. 2003. Healthy Democracy: Bringing Trustworthy Information to the Voters of America. Edina: Beaver's Pond Press.

Cuesta, M. et al. 2008. "Encuesta deliberativa: ¿Cómo sería una opinión pública informada?." Estudio CIS n² 2668, Bolletín CIS 4.

Cuny C. 2009. Appropriation de l'espace et prise de parole: enquête socio-ethnographique sur la participation des habitants dans un quartier de grand ensemble à Berlin-Est. PhD in Sociology, University Paris 8 and Humboldt University of Berlin.

Cuny $C$. and C. Herzberg. "La mobilisation des savoirs citoyens dans les budgets participatifs allemands: l'exemple de la region de Berlin Brandebourg." Pp. 119-145 in Savoirs en débats, edited by S. Topçu, C. Cuny and K. Serrano-Velarde. Paris: L'Harmattan.

Dienel, P. 1978. Die Planungszelle: der Bürger plant seine Umwelt. Opladen: Westdeutscher Verlag.

Dewey, J. 1927. The Public and its Problems. New York: Henry Holt and Company.

Epstein, S. 1995. "The construction of lay expertise: AIDS activism and the forging of credibility in the reform of clinical trials." Science, Technology, and Human Values 20(4):416. 
Fishkin, J. 1995. The Voice of the People: Public Opinion and Democracy. New Haven: Yale University Press.

Font, J. dir. 2001. Ciudadanos y decisiones públicas. Barcelona: Ariel.

Freire, P. 1974. Pedagogia dos oprimidos. São Paolo: Paz e Terra.

Fung, A. and E. O. Wright. 2003. Deepening Democracy: Institutional Innovations in Empowered Participatory Governance. London/New York: Verso.

Ganuza, E. 2010. "Espagne: les origines des budgets participatifs." Pp. 23-41 in La démocratie participative inachevée: genèse, adaptations et diffusions, edited by M.-H Bacqué et al. Paris: ADELS/ Yves Michel.

Ganuza, E. et al. 2011. La democracia en acción: una visión desde las metodologías participativas, Antígona. Consulta 21 de Octubre del 2011 (http://www.antigona.org.es/area-trabajo/lademocraciaenaccion.pdf).

Ganuza, E., Garrido, F. and R. Lafuente. 2009. "Los Andaluces y el agua: encuesta deliberativa." Ponencia presentada en el seminario del IESA, Córdoba, el 15 de mayo de 2009.

Hatzfeld, H. 2005. Faire de la politique autrement: les expériences inachevées des années 1970. Rennes: Presses universitaires de Rennes/ADELS.

Jorba, L. 2009. Deliberación y preferencias ciudadanas: un enfoque empírico. La experiencia de Córdoba. Madrid: CIS.

Lahire, B. 2004. "Utilité: entre sociologie expérimentale et sociologie sociale." Pp. $43-66$ in A quoi sert la sociologie?, edited by B. Lahire. Paris: La Découverte.

Lee A. M. 1976. "Sociology for whom?." American Sociological Review 41: 925-936.

Lorenzana C., Basagoiti M. and Bru P. 2001. IAP de bolsillo. Madrid: ACSUR Las Segovias.

Lorenzo A. R. and M. Martínez. 2001. Asambleas y Reuniones. Torrecedeira: Traficantes de Sueños.

Lynd R. 1939. Knowledge for What? The Place of Social Science in American Culture. Princeton: Princeton University Press.

Mills, C. W. 1959. The Sociological Imagination. London: Oxford University Press.

Nez, H. 2011. "Nature et légitimités des savoirs citoyens dans l'urbanisme participatif: une enquête ethnographique à Paris." Sociologie 4: 387-404.

Nez, H. 2010. "Les savoirs citoyens dans l'urbanisme participatif : regards croisés sur les expériences de Paris et Cordoue." PhD in Sociology, University Paris 8/Autonomous University of Barcelona.

Nez, H. and J. Talpin. 2010. "Généalogies de la démocratie participative en banlieue rouge: un renouvellement du communisme municipal en trompe-l'œil?.” Genèses 79: 97-115.

Nonjon, M. 2006. "Quand la démocratie se professionnalise: enquête sur les experts de la participation." $\mathrm{PhD}$ in Political science, University Lille 2.

Piotte, J. M. 1970. La pensée politique de Gramsci. Montréal: Éditions Parti-Pris.

Rimbert P. 2011. "La pensée critique dans l'enclos universitaire." Le Monde Diplomatique, Janvier, 26-27. 
Santos, B. Eds. 2006 [2002]. Democratizing Democracy: Beyond the Liberal Democratic Canon. London/New York: Verso.

Roux, A. 2011. 50 ans de démocratie locale: comment la participation citoyenne s'est laissée endormir, pourquoi elle doit reprendre le combat. Paris: ADELS/Yves Michel.

Sintomer, Y. 2008. "Du savoir d'usage au métier de citoyen?” Raisons politiques 31:115-134.

Sintomer, Y. and J. Talpin. 2011. La démocratie participative au-delà de la proximité: le Poitou-Charentes et l'échelle régionale. Rennes: Presses universitaires de Rennes.

Smith, G. 2009. Democratic Innovations. Cambridge University Press: Cambridge.

Touraine, A. 1978. La voix et le regard. Paris: Seuil.

Villasante, T. R. 2006. Desbordes creativos: Estilos y estrategias para la transformación social. Madrid: Catarata.

Villasante, T. R. 1995. Las democracias participativas. Madrid: HOAC.

Weber, M. 2004 [1919]. The Vocation Lectures: "Science as a Vocation", "Politics as a Vocation." Indianapolis: Hackett Publishing.

Weber, M. 1966 [1947]. The City. Cambridge: The Free Press.

Werner, M. and B. Zimmermann. eds. 2004. De la comparaison à l'histoire croisée. Paris: Seuil.

Wynne, B. 1996. "May the sheep safely graze? A reflexive view of the expert-lay knowledge divide." Pp. 44-83 in Risk, Environment and Modernity: Toward a New Ecology, edited by S. Lasch, B. Szerszynski and B. Wynne. London: Sage.

HÉLoïse Nez is PhD in Sociology (Université Paris 8 / Universidad Autónoma de Barcelona), Lecturer of Sociology at the Université de Tours and Researcher in the UMR CITERES (Cités, territoires, environnement et société). The main topics of her research are local participatory democracy, social movements and citizen competences.

RECEIVED: 9 February 2012

ACCEPTED: 15 October 2912 